\title{
Carrot-Weed: A Noxious Plant That Threatens Biodiversity in Africa
}

\author{
Neema C. Mtenga*, Thadeo Mokiti Tarimo, Patrick A. Ndakidemi, Ernest R. Mbega \\ Department of Sustainable Agriculture and Biodiversity Ecosystem Management, School of Life Science and Bioengineering, The \\ Nelson Mandela African Institute of Science and Technology, Arusha, Tanzania \\ Email: *nmtenga@yahoo.com
}

How to cite this paper: Mtenga, N.C., Tarimo, T.M., Ndakidemi, P.A. and Mbega, E.R. (2019) Carrot-Weed: A Noxious Plant That Threatens Biodiversity in Africa. American Journal of Plant Sciences, 10, 433-446. https://doi.org/10.4236/ajps.2019.103031

Received: September 27, 2018

Accepted: March 17, 2019

Published: March 20, 2019

Copyright (c) 2019 by author(s) and Scientific Research Publishing Inc. This work is licensed under the Creative Commons Attribution International License (CC BY 4.0).

http://creativecommons.org/licenses/by/4.0/

(c) (i) Open Access

\begin{abstract}
Carrot-weed (Parthenium hysterophorous L.) is a flowering plant of the Asteraceae family (tribe: Heliantheae). The weed became famous due to its notorious invasive role in the environment and agricultural fields. The plant has arisen as the seventh most disturbing weed globally. In Africa, the weed is spreading very fast and information on its biology, impact, and management is scarce. Therefore, this review provides general information about the carrot weed's current distribution status and its impact on agricultural crops, animals and human health in Africa. The review also highlights areas for research in managing this noxious weed in the African habitats.
\end{abstract}

\section{Keywords}

Invasive Species, Biodiversity, Parthenium hysterophorous, Carrot-Weed, Allelopathy

\section{Introduction}

Carrot-weed (Parthenium hysterophorous L.), also known as "bitter weed" or "broom bush" or "congress grass" (in India) or "whitetop" or "feverfew" (in the Caribbean) or "false ragweed" or "ragweed parthenium" (in the USA) is a member of the family Asteraceae [1]. It is a noxious well-known weed that disrupts biodiversity in many parts of the world [2]. Carrot weed derived its Latin name Parthenium hysterophorous from three terms namely "parthenice" (Latin) and is the reference to the plant known as Tanacetum parthenium (L.) and Greek word hystera (Womb) and phoros (bearing), referring to the prolific seeding habit of the plant [3] [4]. It originated from the region adjacent to the Gulf of Mexico, which includes Southern USA, or in central South America [5]. The plant grows in both humid and sub-humid tropics and is favored by weightier 
fertile soil, such as black, alkaline clay loam, but has ability to grow on a wide variety of soil types from sea level up to $1800 \mathrm{~m}$ [6] [7]. The plant also grows mostly in places with summer rainfall greater than $500 \mathrm{~mm}$ per annum [8]. Carrot-weed seed germinates at temperatures between $8^{\circ} \mathrm{C}$ and $30^{\circ} \mathrm{C}$ [9]. The plant has the ability to colonize new habitats rapidly by producing a large number of seeds, which are eventually widely dispersed through vehicles, water, animals, farm machinery and wind, and grows in distressed areas around buildings and fallow agricultural land where inter-specific competition is very low [10]. Carrot-weed is recorded in the global invasive species database and has been reported to invade about 30 countries worldwide [11]. The weed is widespread in North and South America, Caribbean, Lesser Antilles, Australia, India, and Africa [12]. In Africa, the plant was first recorded in southern parts of Africa in 1880s [13]. There exists no clear documentation on how this weed entered Africa; however, some assumptions are that it was possibly introduced to Ethiopia through food grain contaminants in a food aid programme [14]. Currently, the plant is present in many countries of Africa (Figure 1) [15] [16] [17]. Carrot weed is known to compete with indigenous grasses and herbaceous plants used for grazing worldwide [18] thereby, reducing forage productivity by $90 \%$. Furthermore, carrot weed is heavy feeder plant utilizing most of the soil nutrients which ultimately leads to soil infertility, hence resulting to poor crop and animal health [19] [20] [21]. In human, carrot weed has been reported to cause health problems such as asthma, bronchitis, dermatitis and hay fever once it comes into contact with the body [14].

Despite the fact that this weed is very harmful, limited literature is available on the biology and impacts on the biodiversity in Africa. Thus this review provides general information of the carrot weed's current distribution status and its impact on agricultural crops, animals and human health in Africa.

\section{Biology of Carrot-Weed}

Carrot-weed is an annual, erect herb with the height of 1.0 to more than $2.0 \mathrm{~m}$. It

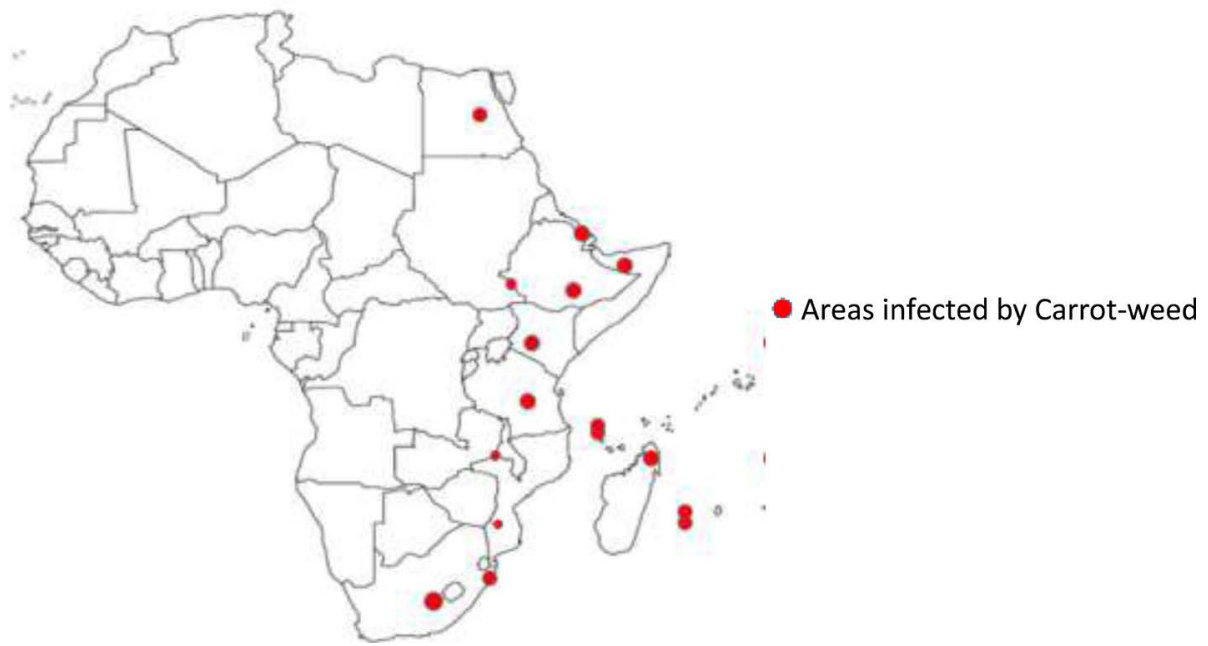

Figure 1. Distribution of carrot-weed in Africa (CAB 2018). 
has a taproot system with a number of secondary and tertiary roots [22]. The plant is fast maturing and has dark green leaves which are rhomboidal, dissected and alternately arranged on the stem [23]. It has white or yellow flowers based on race type each of which produces four to five black wedge-shaped seeds that are $2 \mathrm{~mm}$ long with thin white scales and difficult to see by the naked eye [23]. The leaves and stems have small hair-like outgrowths called trichomes. Its inflorescence is capitulum with cypsela fruits and they produce thousands of seeds which are dark brown and very light in weight [23].

Once the weed dominates an area becomes aggressive, destructive and oppressive to other plant species [20] [24] [25]. The weed spreads very fast due to its ability to produce a greater amount of seeds up to 25,000 seeds/plant which results into a significant amount of seed bank in the soil [23]. This morphological feature of the carrot weed seed enables it to be dispersed in multiple ways including short distance wind dispersal, or water surface, runoff in natural streams and rivers, in irrigation and drainage channels and irrigation water from the ponds. [15] [26] [27] Furthermore, seeds of this weed can be stored in fresh water for about five years and still can germinate [28]. Under favorable moist environment, the seeds can germinate within a week. Generally the life cycle of this weed completed within 180 - 240 days [29]. Carrot weed has two races namely south race and north race. The south race occurs in Southern America while north race occurs in North America and distributed worldwide [30]. These races differ in morphology and biochemical properties where the South America race has hymenin as a dominant sesquiterpene lactone and pathenin for North America race. The North America race produces white flowers while that of South American race are yellow [31].

Regardless of the available information, still there is a need to study the environmental factors which can affect the biology of this weed. This will be helpful since it will provide a way forward on how to control it by using the natural methods which are environmentally friendly that cannot affect the existence of other nearby plants hence improving the biodiversity.

\section{Picture of carrot-weed}

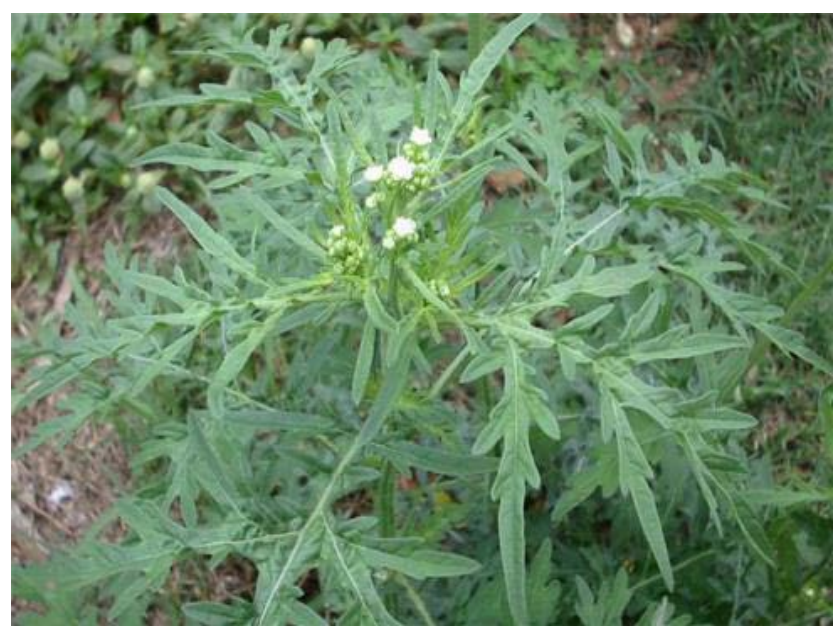




\section{Allelopathic Effects of Carrot-Weed on Plants}

[32] defined allelopathy as a biological occurrence where one plant inhibits the growth of another plant through the release of allelochemicals. The idea of allelopathy was studied broadly for the first time in the forestry ecosystems, where initially it was revealed that most of the forestry species surveyed had unwanted allelopathic effects on food and fodder crops [32] [33] pondered both beneficial and harmful allelochemicals influences by defining allelopathy as the capability of the plant to hinder or stimulate growth of other plants in the surrounding by exuding chemicals. Based on this definition, it's apparent that the oppressive nature of carrot weed is associated with its allelopathic effects caused by sesquiterpene lactones, parthenin, and coronopilin, [34] (Figure 2). These allelochemical groups act synergistically and significantly reduces seed germination and delayed growth of other crops [35]. Also, it was reported that allelochemicals such as tannis, saponins, cardiac glycosides, terpenoids, and steroids are founder on the upper parts of Parthenium, [36]. All these chemicals have an effects on crops and animals. The leaves and inflorescence contain a higher level of allelochemicals than the stem and roots. These allelochemicals affects other plants either directly by leaching, root exudation, and residue decay.

[37] or indirectly leading to the loss of native flora.

According to [38], the weed can degrade the natural ecosystem due to its high capacity of invasiveness and its potential allelopathic properties which disrupt any natural ecosystem. Nevertheless, the weed was reported to cause a decline undesirably the herbaceous components of vegetation up to $90 \%$ due to its destructive nature of competition and allelopathic effect [39] [40]. It is reported to cause great change of native habitat in grassland, open woodland, floodplains and rivers [41] [42] [43]. Therefore, studies on plant species with allelopathic effects to this noxious weed are urgently needed. Further, studies on the chemistry of the plant to elucidate information on chemical composition from different parts of the plant are required for proper management of the weed in Africa.

\section{Impacts on Growth and Yield of Crops}

Carrot-weed has been reported to result in food insecurity (Figure 3) due to decline

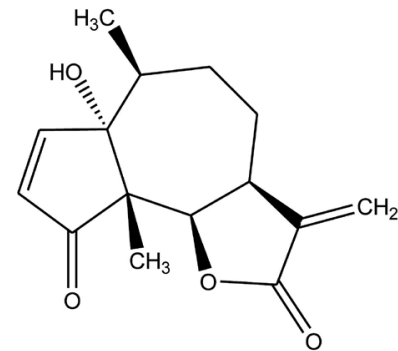

Parthenin

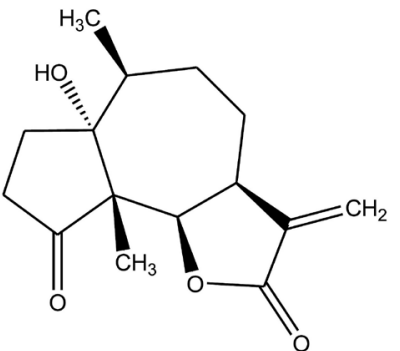

Coronopilin

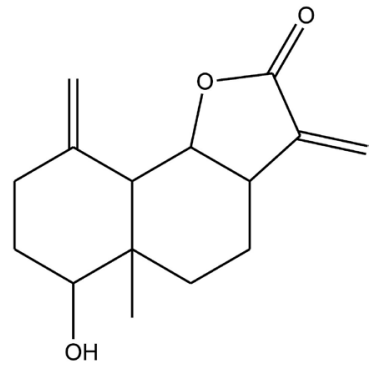

sesquiterpene lactones

Figure 2. Shows allelochemical groups found in Carrot-weed namely: parthenin, coronopoilin and sesquiterpene lactones. 


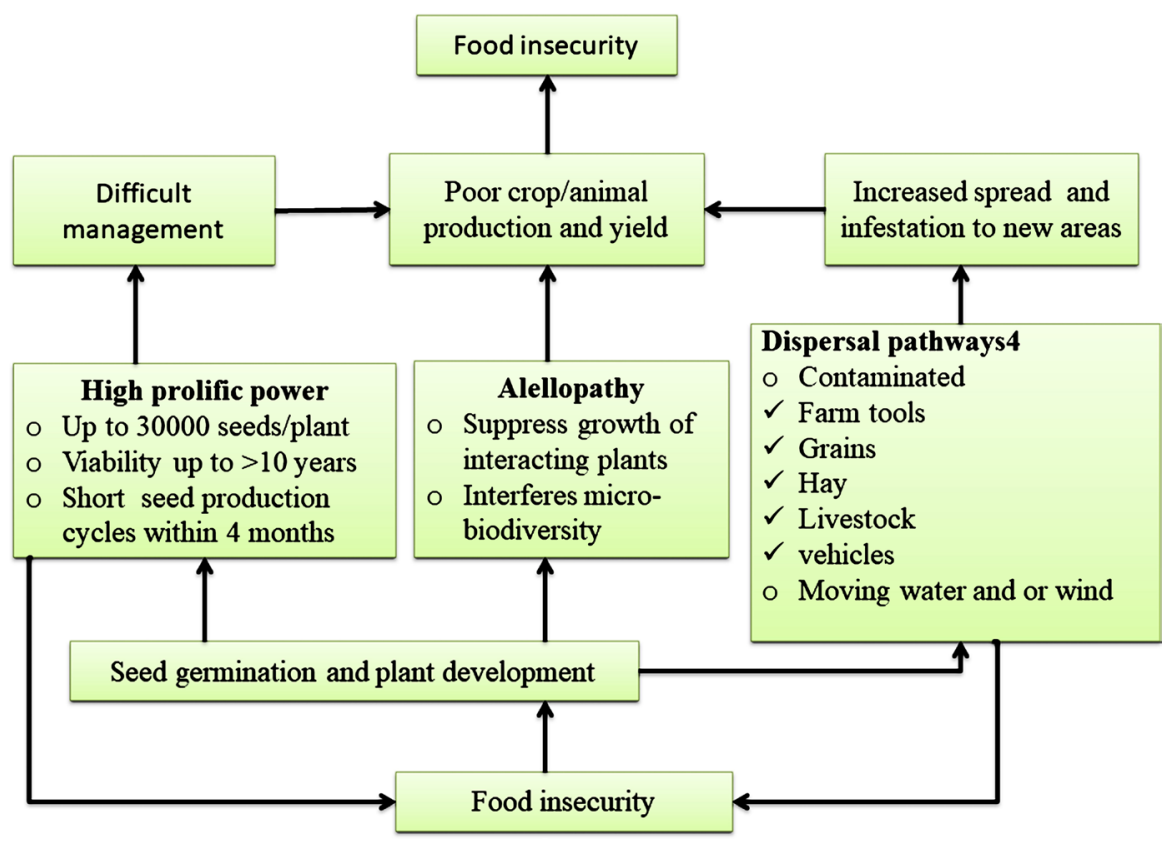

Figure 3. Relationship between carrot-weed and food insecurity.

in agricultural yields of crops and domestic animals to levels of up to $40 \%$ to $90 \%$ [44] [45]. It is also reported to reduce the carrying capacity of pasture crops of up to $90 \%$ [46] [47] [48]. The laboratory experiment and field studies by [43] shows that all plant parts of the carrot weed (shoot, root, inflorescence, and seed) are toxic to other plants. This brings changes in the physical and chemical characteristics of the soil such as soil $\mathrm{pH}$, soil organic matter, phosphorus, and others [49]. Although numerous information exists on the effects of this noxious weed, still there is lack of information on how it affects and induces changes to soil $\mathrm{pH}$ and structure. This calls further urgent investigation.

\section{Impacts of Carrot-Weed on Animals}

Carrot-weed produces toxic substance such as parthenin as described earlier which is harmful to animals when feed on it or coming into contact, causing both dermatitis with distinct skin lesions on various animals including horses and cattle's [35]. Once eaten by animals, it can cause mouth ulcers with excessive starvation [50] [51] reported that carrot-weed causes anorexia, pruritus, alopecia, diarrhea, and eye irritation in animals such as dogs and acute illness, bitter milk and tainted meat in animals such as buffaloes, goat, and cows [52]. Also, experimental work reported that the plant weakens the immune system by reducing the number of white blood cells (WBC) in rats [52]. Further, the weed lowers forage productivity by $90 \%$, reduce land fertility weakens the land and make it infertile and hence lowers the quality weakens the quality of the grazing land. All these cause poor animal health both domesticated and the wildlife since most of them feed on the grasses [48]. Regardless of the information provided on the impacts of this weed on animals, still there is a need for more research on how this weed exactly affect the animals once feed on them. 


\section{Impact of Carrot-Weed on Human}

Carrot-weed has been reported to cause human health problem such as asthma, bronchitis, dermatitis, hay fever when exposed to it [53] [54], allergic eczematous and mental depression [55]. Furthermore, carrot-weed lead to general illness, annoyances of skin and pustules on handballs, extending and furious of skin and stomach pains on humans [56]. Human contact with carrot-weed followed with exposure to sun results to health effects such as violaceous papulae, as well as a plaque on exposed parts such ears, forehead, cheek and upper chest. Nevertheless, health effects like hyperkeratotic papule and prurigo nodules have been associated with exposure to carrot-weed [57]. On other hands, [58] further showed that dermatitis health effects are due to the presence of a cytotoxic compound sesquiterpene lactone Parthenin. Apart from that, exposure to carrot-weed was further correlated with diarrhea, breathlessness, and chocking as well as erythematous eruptions [58]. Allergic bronchitis was also associated with exposure to carrot-weed, however, no signs of mutagenicity and genotoxicity have been observed [58]. In addition, exposure to carrot weed has shown positive reactions to mAb-2 as well as cytokines [58]. In general, these effects are classified into four categories: airborne contact dermatitis $(A B C D)$, chronic actinic dermatitis (CAD) and the combination of $A B C D$ and $\mathrm{CAD}$ and lastly exposure to the sun (photosensitive lichenoid) [57]. Therefore there is a need of more research to know exactly the compounds present in the pollen of this weed which is responsible for the health problems to a human being to make easy management with precaution during physical control practice.

\section{Impacts of Carrot-Weed on Biodiversity}

According to [13] carrot-weed is on of harmful invasive species in the World and an increasing problem in Africa. Its invasion results into the degradation of the natural ecosystem and biodiversity due to its high invasion capacity [39]. Further, it has been reported that the allelopathic properties of this weed are potential for disrupting the growth and distribution of natural vegetation which in turn affect the diversity of animal [19]. Also, the weed is capable of causing the decline of the species richness and abundance in the natural system as it inhibits the physiological processes of other weed species [59].

In some countries such as Australia, the weed is reported to cause changes in the entire habitat in Australia grassland, open and woodlands, and river banks [37] [60]. Furthermore, [24] reported that Parthenium weed has a negative impact on the structural composition on dynamic and diversity of the plant and animals in India. It also affects not only the species diversity of native areas but also their ecological integrity. It has been shown that Parthenium residues are toxic to aquatic flora and fauna [61]. Table 1 summarizes the general impacts of carrot-weed on crops, animals, and biodiversity in general. 
Table 1. Some of the reported impacts of carrot-weed (P. hysterophorous).

\begin{tabular}{|c|c|c|c|}
\hline Categories & Mode of action & Effects & References \\
\hline Crops (legumes \&cereals). & The release of phytotoxic compounds & $\begin{array}{l}\text { Reduced crop yield as well as carrying capacity } \\
\text { of pastures. }\end{array}$ & [44] [46] [48] \\
\hline Wild animals/livestock & $\begin{array}{c}\text { Weakens the immune system by reducing the } \\
\text { number of WBC }\end{array}$ & $\begin{array}{l}\text { Skin lesions, mouth ulcers, anorexia, pruritus, } \\
\text { alopecia, diarrhea, eye irritation. }\end{array}$ & $\begin{array}{l}{[35][50][51]} \\
\quad[52][58]\end{array}$ \\
\hline Human health & $\begin{array}{c}\text { Induction of cytotoxicity also reacts with } \\
\text { cytokines. }\end{array}$ & $\begin{array}{l}\text { Allergic, bronchitis, skin inflammation, asthma, } \\
\text { blisters, hay fever, erythematous eruption }\end{array}$ & [53] [55]. \\
\hline Soil & Utilizing soil nutrients & Soil infertility & {$[48][52]$.} \\
\hline \multirow[t]{2}{*}{$\begin{array}{l}\text { Vegetation/landscape } \\
\text { composition }\end{array}$} & $\begin{array}{l}\text { Disrupt the structure of the natural ecosystem } \\
\text { and displace numerous native plant species. }\end{array}$ & $\begin{array}{l}\text { Degradation of natural ecosystem and } \\
\text { biodiversity, allelopathic effects, toxic to flora } \\
\text { and fauna, reduced species richness. }\end{array}$ & [59] [61] \\
\hline & Shrinking of biodiversity & & \\
\hline
\end{tabular}

\section{Management and Control}

The use of biocontrol agents such as (Insects and fungal pathogens) and use of competitive plants (allelopathy) is suggested as the greatest cost-effective and practical way of managing Parthenium [62]. However, the management of the weed has not been well developed below the edge level and the weed continues to threaten biodiversity by posing ill problems to humans and animals. Therefore several methods, for example, physical, mechanical, chemical and use of allelopathic plants are being practiced to manage this weed around the globe.

\section{Physical and Mechanical Methods}

These are the most common methods used in the management of carrot-weed in many countries. The methods are widely used as they are cheaper, easy to apply and are cost effective. Farmers manage the weed by hand uprooting or using a hoe in their fields, collect and burn before flowering time. Despite, the success of this method, it is faced with many challenges including the frequent growth of the weed [29].

\section{Chemical Control}

Management of carrot-weed by using chemical method seems to be popular in most developed countries such as India where the weed has spread in large areas. This method mostly used to remove the weed from the area in time, therefore the issue of time is very important for this type of management. Application of the chemicals should be done at the early stages to prevent flowering and seed setting. The spraying of the herbicides which are not harmful to other plants which are growing nearby the weed is mostly recommended to reduce the infestation. Despite the fact that chemical control is the most common method employed, it is reported to be less effective due to the development of resistance [63]. Therefore, there is a need for developing bio-management strategies for management of this weed rather than the use of chemicals which are no more 
reliable and sometimes harmful to the environment.

\section{Biological Control}

Although the use of chemical seems to be most applicable in many countries in the management of Parthenium, yet the method has been reported to have many negative impacts in the environment [64]. The bio-control strategy is the most applicable way used in managing the weed by manipulating natural enemies to control others. The biological control method is less cost, environmentally friendly and ecologically practicable method. Several insects and pathogens have been used in the control of this weed. For instance, leaf feeding (Zygogramma bicolorata) and stem-galling moth (Epiblema strenuana) have been used to control this weed and have shown efficacy in reducing the number of seeds and leaves especially at the young stage [65] [66]. Also, the use of fungus is now regarded as a bio-control strategy of Parthenium among others, example; Fusarium pallidoroseum, Puccinia melampodii and Oidium parthenii [67]. Studies conducted by [68] shows that the use of microorganisms as a biological agent as a strategy for controlling this weed control has many advantages such as higher selectivity, their capacity to inhibit plant growth, the lower potential to resist, lower production costs.

Therefore, there is a need of using botanicals and microorganisms in controlling this weed because they are environmentally friendly, easy to apply and such resources are readily available in our environment.

\section{Use of Suppressive Plants as a Management Strategy}

Different literature shows that there are some plants/weeds which have been used to manage this weed and become successful. According to [69], the herbicidal extracts from Tagetes erictus obtained from roots, shoots, and flowers reduced root and shoot length of carrot-weed. Also, another study by [70] reported extracts from the roots and shoots of sorghum had significant impacts on the growth of the carrot-weed. Moreover [71] reported that the extracts and residues of Amaranthus spinosus significantly reduced the growth of carrot-weed by inhibiting the height of the plant, length of leaves and number of branches, capitula, and the seed of the plant.

Despite of the above research efforts of using suppressive plants which has impacts on growth and germination of Carrot-weed, yet more research is needed to know the chemical contents of the suppressive plants used so that to build a more scientific management approach of managing this weed by using suppressive plants.

\section{Current Research Gaps}

Several management approaches such as physical, chemical herbicide and biological control have been tried to control this weed only herbicides approach seem to be preferred by farmers in many parts of the world including Africa (Kumar; 2009) (Table 2). Nevertheless, chemical herbicides are no longer reliable 
Table 2. Summarizing the management approaches for carrot-weed.

\begin{tabular}{|c|c|c|c|c|}
\hline Methods & How was applied & Items used & Results & References \\
\hline Physical control & $\begin{array}{l}\text { the burning of the surface } \\
\text { part and seeds near the } \\
\text { surface and crop rotation }\end{array}$ & Tagetes sp. and Fire & $\begin{array}{l}\text { Reduce infestation and } \\
\text { spreads. }\end{array}$ & [13] [66] \\
\hline Chemical control & $\begin{array}{l}\text { Many chemical pesticides } \\
\text { applied both in cropped } \\
\text { and non-cropped } \\
\text { condition }\end{array}$ & $\begin{array}{c}\text { Glyphosate (1 to } 1.5 \mathrm{~kg} / \mathrm{ha} \text { ) diquat } 0.5 \\
\mathrm{~kg} / \mathrm{ha} \text { in } 500 \text { liters, }\end{array}$ & $\begin{array}{c}\text { Control } \\
\text { Parthenium in all stages. But } \\
\text { only kills the target } \\
\text { population }\end{array}$ & [72] [73] \\
\hline Biological control & $\begin{array}{l}\text { Through the introduction } \\
\text { of control agents in the } \\
\text { affected fields. Spraying of } \\
\text { foliar extracts }\end{array}$ & $\begin{array}{l}\text { Microbial pathogens (like Fusarium } \\
\text { pallidoroseum, Puccinia melampodii } \\
\text { and Oidiumparthenii), Insects: } \\
\text { (Zyogramma bicolorata, Bucculatrix } \\
\text { parthenica (leaf-mining moth), } \\
\text { Smicronyx lutulentus,) Fungil } \\
\text { (Fusarium pallidoroseum, Puccinia } \\
\text { melampodii and Oidium parthenii) }\end{array}$ & $\begin{array}{l}\text { Reduce flowers and seed } \\
\text { production, Inhibit } \\
\text { germination }\end{array}$ & {$[65][66][74][75][76]$} \\
\hline
\end{tabular}

Advantages and Disadvantages of different methods used in management of Carrot-weed

\begin{tabular}{|c|c|c|}
\hline Methods & Advantages & Disadvantages \\
\hline Mechanical Methods & Cheap, simple, easy to practice & $\begin{array}{l}\text { Time consuming, high risk of being affected if the weed reaches } \\
\text { flowering stage, Energy consuming methods. Also once involve } \\
\text { burning it may kills some useful pants. }\end{array}$ \\
\hline Chemical Method & $\begin{array}{l}\text { Effective method in the absence of natural enemies, } \\
\text { Prevent any emerging of weeds in the area where it } \\
\text { sprayed, Cause complete kill of the weed. }\end{array}$ & $\begin{array}{l}\text {-It is environmental hazards } \\
\text {-Development of some resistance against herbicides } \\
\text { - Damage flora and fauna } \\
\text {-Ground water contamination } \\
\text {-Reduce soil quality } \\
\text {-Very costly in term of money }\end{array}$ \\
\hline Suppressive plants & $\begin{array}{l}\text {-Reduce seed germination } \\
\text {-Suppress early seedling growth }\end{array}$ & $\begin{array}{l}\text {-Time consuming } \\
\text {-Difficult to measure its degree of suppression }\end{array}$ \\
\hline
\end{tabular}

due to the cost and increasing weed resistance to polyphosphate, atrazines, 4-D, and Metribuzin (Vila-Aiub et al., 2008). Need for other options including development of eco-friendly approaches such as plant-based biopesticides and or agro-ecological principles based on weed-weed completion are currently receiving great attention as a vital pest control strategy worldwide (Marcías et al., 2004; Vasilakoglou et al., 2005; Dhima et al., 2006; Javaid et al., 2008). Thus and similarly for the African setting, there is need to develop eco-friendly weed management strategy involving but not limited to biopesticides for managing carrot weed. Plants such Azadirachta indica, Eucalyptus tereticornis, Tagetes erictus, Sorghum spp, Cassia tora and Amaranthus spinous can be targeted as potential competitors in weed-weed completion or in testing their extracts against carrot weed based on report by Kaur (2014). 


\section{Conclusion}

Although many efforts have been exercised to reduce the spread of carrot weed in many countries, its colonization onto the African habitats is already noxious, impacting the Biodiversity. Of the preferred weed control options, chemical herbicides seem to be popular despite its harmful effects to the environment and human health. In addition, a chemical herbicide application is constrained by development of resistance by the weed. Therefore, beside showing how noxious carrot-weed is to the African Biodiversity, this review has also indicate the gaps of knowledge that needs to be addressed most of which besides knowledge of the weed biology highlights a need for exploration sustainable weed management techniques such use of botanical herbicides as these are believed to be environmentally friendly and cost-effective.

\section{Conflicts of Interest}

The authors declare no conflicts of interest regarding the publication of this paper.

\section{References}

[1] Picman, J. and Picman, A.K. (1984) Autotoxicity in Parthenium hysterophorus and Its Possible Role in Control of Germination. Biochemical Systematics and Ecology, 12, 287-292. https://doi.org/10.1016/0305-1978(84)90051-6

[2] Timsina, B., et al. (2011) Impact of Parthenium hysterophorus L. Invasion on Plant Species Composition and Soil Properties of Grassland Communities in Nepal. Flora-Morphology, Distribution, Functional Ecology of Plants, 206, 233-240. https://doi.org/10.1016/j.flora.2010.09.004

[3] Parsons, W.T., Parsons, W.T. and Cuthbertson, E. (2001) Noxious Weeds of Australia. CSIRO Publishing.

[4] Navie, S., et al. (1996) The Biology of Australian Weeds. 27. Parthenium hysterophorus L. Plant Protection Quarterly, 11, 76-88.

[5] Kaur, M., et al. (2014) Effects and Management of Parthenium hysterophorus: A Weed of Global Significance. International Scholarly Research Notices, 2014.

[6] Taye, T., et al. (2002) The Potential of Pathogens as Biological Control of Parthenium Weed (Parthenium hysterophorus L.) in Ethiopia. Mededelingen (Rijksuniversiteit te Gent. Fakulteit van de Landbouwkundige en Toegepaste Biologische Wetenschappen), 67, 409-420.

[7] Kebede, A. (2008) The Distributions of Parthenium Weed (Parthenium hysterophorus L. Asteraceae) and Some of Its Socio-Economic and Ecological Impacts in the Central Rift Valley, Adami Tulu-Jido Kombolcha Woreda. Addis Ababa University, Ethiopia.

[8] Chamberlain, J. and Gittens, A. (2004) Parthenium Weed Management: Challenges, Opportunities and Strategies. Parthenium Action Group. The State of Queensland (Department of Natural Resources, Mines and Energy), Brisbane, 82.

[9] Rajiv, P., Rajeshwari, S. and Venckatesh, R. (2013) Bio-Fabrication of Zinc Oxide Nanoparticles Using Leaf Extract of Parthenium hysterophorus L. and Its Size-Dependent Antifungal Activity against Plant Fungal Pathogens. Spectrochimica Acta Part A: Molecular and Biomolecular Spectroscopy, 112, 384-387. 
https://doi.org/10.1016/j.saa.2013.04.072

[10] Auld, B., Hosking, J. and McFadyen, R. (1982) Analysis of the Spread of Tiger Pear and Parthenium Weed in Australia. Australian Weeds, 2, 56-60.

[11] Kohlil, F., et al. (2011) Invasive Alien Plants: An Ecological Appraisal for the Indian Subcontinent. Journal of the Indian Botanical, $1,1$.

[12] Roy, D. and Shaik, M.M. (2013) Toxicology, Phytochemistry, Bioactive Compounds and Pharmacology of Parthenium hysterophorus. Journal of Medicinal Plants Studies, 1, 126-141.

[13] McConnachie, A., et al. (2011) Current and Potential Geographical Distribution of the Invasive Plant Parthenium hysterophorus (Asteraceae) in Eastern and Southern Africa. Weed Research, 51, 71-84. https://doi.org/10.1111/j.1365-3180.2010.00820.x

[14] Adkins, S. and Shabbir, A. (2014) Biology, Ecology and Management of the Invasive Parthenium Weed (Parthenium hysterophorus L.). Pest Management Science, 70, 1023-1029. https://doi.org/10.1002/ps.3708

[15] Nigatu, L., et al. (2010) Impact of Parthenium hysterophorus on Grazing Land Communities in North-Eastern Ethiopia. Weed Biology and Management, 10, 143152. https://doi.org/10.1111/j.1445-6664.2010.00378.x

[16] Ayele, S., Nigatu, L., Tana, T. and Steve Adkins, W. (2013) Impact of Parthenium weed (Parthenium hysterophorus L.) on the Above-Ground and Soil Seed Bank Communities of Rangelands in Southeast Ethiopia. International Research Journal of Agricultural Science and Soil Science, 3, 262-274.

[17] Ramadhan Kilewa, A. (2014) Distribution of Invasive Weed Parthenium hysterophorus in Natural and Agro-Ecosystems in Arusha Tanzania. International Journal of Science and Research, 3, 1724-1727.

[18] Evans, H.C. (1997) Parthenium hysterophorus. A Review of Its Weed Status and the Possibilities for Biological Control. Biocontrol News and Information, 18, 89N-98N.

[19] Ayele, S. (2007) The Impact of Parthenium (Parthenium hysterophorus L.) on the Range Ecosystem Dynamics of the Jijiga Rangeland, Ethiopia. Department of Animal Sciences, School of Graduate Studies, Haramaya University, Haramaya, 134.

[20] Bhowmik, P. and Sarkar, D. (2005) Parthenium hysterophorus. Its World Status and Potential Management. Proceedings of the 2 nd International Conference on Parthenium Management, University of Agricultural Sciences, Bangalore, 5-7 December 2005, 1-6.

[21] Worku, M. (2010) Prevalence and Distribution Survey of an Invasive Alien Weed (Parthenium hysterophorus L.) in Sheka Zone, Southwestern Ethiopia. African Journal of Agricultural Research, 5, 922-927.

[22] Dogra, K.S., Sood, S.K. and Sharma, R. (2011) Distribution, Biology and Ecology of Parthenium hysterophorus L. (Congress Grass) an Invasive Species in the NorthWestern Indian Himalaya (Himachal Pradesh). African Journal of Plant Science, 5, 682-687.

[23] Javaid, A. and Adrees, H. (2009) Parthenium Management by Cultural Filtrates of Phytopathogenic Fungi. Natural Product Research, 23, 1541-1551. https://doi.org/10.1080/14786410902726167

[24] Kohli, R.K., Dogra, K.S., Batish, D.R. and Singh, H.P. (2004) Impact of Invasive Plants on the Structure and Composition of Natural Vegetation of Northwestern Indian Himalayas. Weed Technology, 18, 1296-1300. https://doi.org/10.1614/0890-037X(2004)018[1296:IOIPOT]2.0.CO;2

[25] Shabbir, A. and Bajwa, R. (2005) Parthenium hysterophorus-Spread and Status on 
Its Management in Pakistan. Proceedings of the 2nd International Conference on Parthenium Management, University of Agricultural Sciences, Bangalore, 5-7 December 2005, 28-35.

[26] Monaco, T.J., Weller, S.C. and Ashton, F.M. (2002) Weed Science: Principles and Practices. John Wiley \& Sons, New York.

[27] Riaz, T. and Javaid, A. (2010) Prevalence of Invasive Parthenium Weed in District Hafizabad. Journal of Animal and Plant Sciences, 20, 90-93.

[28] Adnan, M., et al. (2015) Survey of District Sialkot for the Infestation of Parthenium hysterophorus. Journal of Biology, Agriculture and Healthcare, 5, 111-119.

[29] Gnanavel, I. and Natarajan, S. (2013) Parthenium hysterophorus L.: A Major Threat to Natural and Agro Eco-Systems in India. International Journal of Agriculture, Environment and Biotechnology, 6, 261-269.

[30] Dale, I. (1981) Parthenium Weed in the Americas. Australian Weeds, 1, 8-14.

[31] Annapurna, C. and Singh, J. (2003) Variation of Parthenium hysterophorus in Response to Soil Quality: Implications for Invasiveness. Weed Research, 43, 190-198. https://doi.org/10.1046/j.1365-3180.2003.00332.x

[32] Msafiri, C.J., Tarimo, M.T. and Ndakidemi, P. (2013) Allelopathic Effects of Parthenium hysterophorus on Seed Germination, Seedling Growth, Fresh and Dry Mass Production of Alysicurpus glumaceae and Chloris gayana. American Journal of Research Communication, 1, 190-205.

[33] Jalali, M., et al. (2013) Allelopathic Potential of Common Mallow (Malva sylvestris) on the Germination and the Initial Growth of Blanket Flower, Plumed Cockscomb and Sweet William. International Journal of Agriculture and Crop Sciences, 5, 1638.

[34] Singh, H.P., et al. (2002) Effect of Parthenin-A Sesquiterpene Lactone from Parthenium hysterophorus-On Early Growth and Physiology of Ageratum conyzoides. Journal of Chemical Ecology, 28, 2169-2179. https://doi.org/10.1023/A:1021089013754

[35] Singh, H., Batish, D.R., Pandher, J.K. and Kohli, R.K. (2003) Assessment of Allelopathic Properties of Parthenium hysterophorus Residues. Agriculture, Ecosystems \& Environment, 95, 537-541. https://doi.org/10.1016/S0167-8809(02)00202-5

[36] Neeraja, A. and Vikas, G. (2010) Phytochemical Analysis of Lantana camara and Parthenium hysterophorus. BIOINFOLET, 7, 135-136.

[37] Chippendale, J. and Panetta, F. (1994) The Cost of Parthenium Weed to the Queensland Cattle Industry. Plant Protection Quarterly, 9, 73-76.

[38] Kumar, A. (2014) Parthenium hysterophorus L. and Its Impact on Living World. Indian Journal of Scientific Research, 4, 8-14.

[39] Kapoor, R. (2012) Awareness Related Survey of an Invasive Alien Weed, Parthenium hysterophorus L. in Gautam Budh Nagar District, Uttar Pradesh, India. Journal of Agricultural Technology, 8, 1129-1140.

[40] Mahadevappa, M., Das, T. and Kumar, A. (2001) Parthenium: A Curse for Natural Herbs. Proceedings of the National Research Seminar on Herbal Conservation, Culture, Marketing and Utilization with Special Emphasis on Chhatisgarh-The Herbal State, Raipur, 13-14 December 2001, 9-10.

[41] Riaz, T. and Javaid, A. (2011) Prevalence of Alien Weed Parthenium hysterophorus L. in Grazing and Wastelands of District Attock, Pakistan. Journal of Animal and Plant Science, 21, 542-545.

[42] Shabbir, A., Dhileepan, K. and Adkins, S.W. (2012) Spread of Parthenium Weed and Its Biological Control Agent in the Punjab, Pakistan. Pakistan Journal of Weed 
Science Research, 18, 581-588.

[43] Wakjira, M., Berecha, G. and Tulu, S. (2009) Allelopathic Effects of an Invasive Alien Weed Parthenium hysterophorus L. Compost on Lettuce Germination and Growth. African Journal of Agricultural Research, 4, 1325-1330.

[44] Tamado, T., Ohlander, L. and Milberg, P. (2002) Interference by the Weed Parthenium hysterophorus L. with Grain Sorghum: Influence of Weed Density and Duration of Competition. International Journal of Pest Management, 48, 183-188. https://doi.org/10.1080/09670870110101739

[45] Maharjan, S., Shrestha, B. and Jha, P. (2007) Allelopathic Effects of Aqueous Extract of Leaves Germination and Seedling Growth of Some of Parthenium hysterophorus L. on Seed Cultivated and Wild Herbaceous Species. Scientific World, 5, 33-39. https://doi.org/10.3126/sw.v5i5.2653

[46] Khosla, S. and Sobti, S. (1981) Effective Control of Parthenium hysterophorus Linn. Pesticides, 15, 18-19.

[47] Nath, R. (1988) Parthenium hysterophorus L.-A Review. Agricultural Reviews, 9, 171-179.

[48] Fessehaie, R., Chichayibelu, M. and Hailegeorgis, M. (2005) Spread and Ecological Consequences of Parthenium hysterophorus in Ethiopia. Arem, 6, 1123.

[49] Bhowmik, P., Sarkar, D. and Yaduraju, N. (2007) The Status of Parthenium hysterophorus and Its Potential Management. Ecoprint, 14, 1-17. https://doi.org/10.3126/eco.v14i0.4824

[50] Narasimhan, T. (1977) Toxicity of Parthenium hysterophorus L. Current Science, 46, 15-16.

[51] Aneja, K., Dhawan, S. and Sharma, A.B. (1991) Deadly Weed, parthenium hysterophorus L. and Its Distribution. Indian Journal of Weed Science, 23, 14-18.

[52] Yadav, N., et al. (2010) Effect of Methanolic Extract of Parthenium hysterophorus on Haematological Parameters in Wistar Albino Rat. The Bioscan, 2, 357-363.

[53] Sriramarao, P., et al. (1991) Immediate Hypersensitivity to Parthenium hysterophorus. II. Clinical Studies on the Prevalence of Parthenium rhinitis. Clinical \& Experimental Allergy, 21, 55-62. https://doi.org/10.1111/j.1365-2222.1991.tb00804.x

[54] Kololgi, P., Kololgi, S. and Kololgi, N. (1997) Dermatologic Hazards of Parthenium in Human Beings. Proceedings of the 1 st International Conference on Parthenium Management, Dharwad, 18-19.

[55] Sharma, V.K., Sethuraman, G. and Bhat, R. (2005) Evolution of Clinical Pattern of Parthenium Dermatitis: A Study of 74 Cases. Contact Dermatitis, 53, 84-88. https://doi.org/10.1111/j.0105-1873.2005.00652.x

[56] Wiesner, M., et al. (2007) Impact of the Pan-Tropical Weed Parthenium hysterophorus L. on Human Health in Ethiopia. Institute of Horticultural Science, Urban Horticulture, Berlin.

[57] Jayaramiah, R., et al. (2017) Harmful Effects of Parthenium hysterophorus and Management through Different Approaches-A Review. Annals of Plant Sciences, 6, 1614-1621. https://doi.org/10.21746/aps.2017.05.002

[58] Patel, S. (2011) Harmful and Beneficial Aspects of Parthenium hysterophorus: An Update. 3 Biotech, 1, 1-9. https://doi.org/10.1007/s13205-011-0007-7

[59] Nguyen, T.L., Navie, S.C. and Adkins, S.W. (2010) The Effect of Parthenium Weed (Parthenium hysterophorus L.) on Plant Diversity in Pastures in Queensland, Australia. 17 th Australasian Weeds Conference, New Frontiers in New Zealand: Together We Can Beat the Weeds, New Zealand Plant Protection Society, Christchurch, New Zealand, 26-30 September 2010, 138. 
[60] McFadyen, R.C. (1992) Biological Control against Parthenium Weed in Australia. Crop Protection, 11, 400-407. https://doi.org/10.1016/0261-2194(92)90021-V

[61] Kanchan, S. and Chandra, J. (1980) Pollen Allelopathy-A New Phenomenon. New Phytologist, 84, 739-746. https://doi.org/10.1111/j.1469-8137.1980.tb04786.x

[62] Kohli, R., Rani, D., Singh, H.P. and Kumar, S. (1997) Response of Crop Seeds Towards the Leaf Leachates of Parthenium hysterophorus L. Indian Journal of Weed Science, 28, 104-106.

[63] Culliney, T.W. (2005) Benefits of Classical Biological Control for Managing Invasive Plants. Critical Reviews in Plant Sciences, 24, 131-150. https://doi.org/10.1080/07352680590961649

[64] Commare, R.R., et al. (2002) Pseudomonas Fluorescens Based Bio-Formulation for the Management of Sheath Blight Disease and Leaffolder Insect in Rice. Crop Protection, 21, 671-677. https://doi.org/10.1016/S0261-2194(02)00020-0

[65] Ray, P. and Gour, H. (2012) Integrated Management of Parthenium hysterophorus L. (Asteraceae): A Weed of Worldwide Significance. Indian Society of Mycology and Plant Pathology, 5, 605-632.

[66] Stamps, R.H. (2011) Identification, Impacts, and Control of Ragweed Parthenium (Parthenium hysterophorus L.). University of Florida IFAS Extension, 10.

[67] Florentine, S.K., Raman, A. and Dhileepan, K. (2002) Responses of the Weed Parthenium hysterophorus (Asteraceae) to the Stem Gall-Inducing Weevil Conotrachelus albocinereus (Coleoptera: Curculionidae). Entomologia Generalis, 26, 195-206. https://doi.org/10.1127/entom.gen/26/2002/195

[68] Alavanja, M.C., Hoppin, J.A. and Kamel, F. (2004) Health Effects of Chronic Pesticide Exposure: Cancer and Neurotoxicity. Annual Review of Public Health, 25, 155-197. https://doi.org/10.1146/annurev.publhealth.25.101802.123020

[69] Shafique, S., Bajwa, R. and Shafique, S. (2011) Tagetes Erectus L.-A Potential Resolution for Management of Parthenium hysterophorus L. Pakistan Journal of Botany, 43, 885-894.

[70] Javaid, A. and Anjum, T. (2006) Control of Parthenium hysterophorus L., by Aqueous Extracts of Allelopathic Grasses. Pakistan Journal of Botany, 38, 139.

[71] Thapar, R. and Singh, N. (2005) Allelopathic Influence of Leaf Residue of Amaranthus spinosus on Growth and Metabolism of Parthenium hysterophorus L. Ecoprint, 12, 77-84. https://doi.org/10.3126/eco.v12i0.3203

[72] Kumar, S. (2015) History, Progress and Prospects of Classical Biological Control in India. Indian Journal of Weed Science, 47, 306-320.

[73] Dhanaraj, R. and Mittra, M. (1976) Control of Parthenium hysterophorus L. with Diquat. Proceedings of the National Academy of Sciences of the United States of America, 22, 269-272.

[74] Dhileepan, K. (2003) Current Status of the Stem-Boring Weevil Listronotus setosipennis (Coleoptera: Curculionidae) Introduced against the Weed Parthenium hysterophorus (Asteraceae) in Australia. Biocontrol Science and Technology, 13, 3-12. https://doi.org/10.1080/0958315021000054340

[75] Dhileepan, K. (2001) Effectiveness of Introduced Biocontrol Insects on the Weed Parthenium hysterophorus (Asteraceae) in Australia. Bulletin of Entomological Research, 91, 167-176.

[76] Dhileepan, K. and Wilmot Senaratne, K. (2009) How Widespread Is Parthenium hysterophorus and Its Biological Control Agent Zygogramma bicolorata in South Asia? Weed Research, 49, 557-562.

https://doi.org/10.1111/j.1365-3180.2009.00728.x 